1. 緒言

人工衛星などの宇宙船は、希薄気体との摩摖でエネルギ 一を損失したり、太陽や月の引力、太陽風や地球の地磁気 などの影響を受けたりして安定した軌道、姿勢で地球を周 回できなくなる。これらを制御、修正するのにガスジェッ トが使われる。そのためその噴流と固体面との干渉が重要 である。本研究ではレーザー誘起蛍光法 (Laser Induced Florescence）を用い試料気体（アルゴン）に混合したヨ ウ素分子 $I$, 発光させ、軸が平行な複数のオリフィスか ら出た噴流の干涉を可視化する。LIF は希薄気体流体を可 視化する方法のひとつで、量子効果を利用した最先端の超 音速流診断法である。流れの計測にはピトー管などが用い られるが、超音速流や遷音速流にピトー管を挿入すると衝 撃波が生じ正しい测定ができない場合が多くある。レーザ 一計測の利点としては、計測対象に非接触で、瞬時に高速 測定ができるということであり、LIF はこのような流れを 高い時間的、空間的分解能で測定することが可能である。 2. 基礎理論

ある種の物質にはいろいろなエネルギーを吸収して熱 を伴うことなしに光を発するルミネセンス (luminescence) がある。これらのうち紫外線や可視光 線のような光のエネルギーを吸収して再び光を放射する現 象を光ルミンネセンス (photoluminescence) と呼ぶ。蛍光は 光ルミンネセンスの内の一つであり、光の吸収によって 物質を構成する原子、分子に引き起こされる電子のエレ ルギー準位の変化、すなわち、電子遷移の過程の問題に なる。光の吸収や放射についてはエネルギーを持つ粒子 （光量子：photon）の流れとして説明できる。

Fig1 は分子が励起したときのエネルギーレベルの過程 を表す。

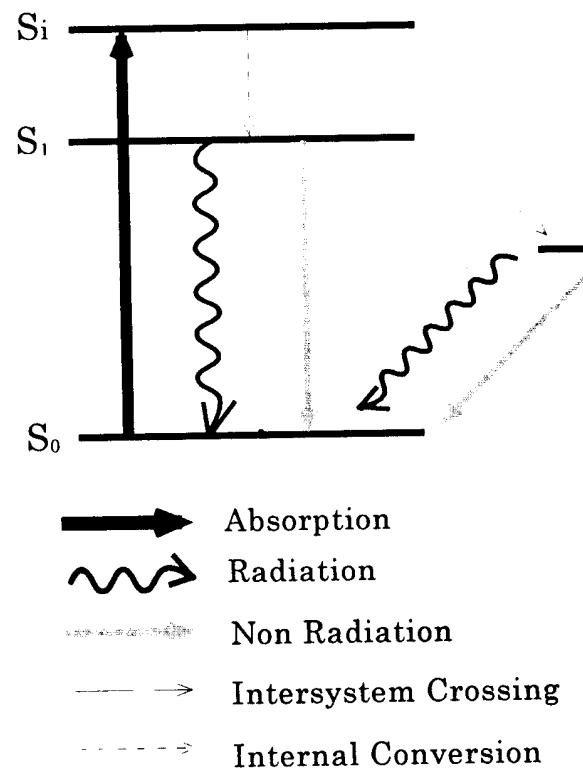

Fig.1 Energy Level Diagram

本研究では蛍光を発するトレーサー分子としてヨウ 素分子を用いた。ヨウ素分子は可視領域の中央に強い吸 収スペクトルを持っており、比較的大きな室温蒸気压、 吸収断面積、そして比較的長い蛍光寿命という利点があ る、そのヨウ素分子の共鳴周波数に一致するようにレー ザ一の周波数を同調させたとき、その分子は基底状態 (ground states) から励起状態（excited states） 一遷移 $\left(\boldsymbol{S}_{0} \rightarrow \boldsymbol{S}_{\boldsymbol{i}}\right)$ する。それらの状態は多くの振動回転準位か ら成っており、それぞれの電子状態を $S_{0} 、 S_{1} 、 S_{i}$ 、と簡 単に表す。 $S_{i}$ にある分子は内部転換 (internal conversion) により $S_{1}$ へ遷移し、さらにその励起状態分子は蛍光と呼ば れるフォトンの自然放射や衝突失活過程を経て基底状態に 遷移する分子と、系間交差(intersystem crossing)による三 重項状態への遷移の後、りん光と呼ばれる放射と無放射失 活過程に分かれて、基底状態に遷移する分子がある。

\section{3. 実験装置および実験方法}

本研究に用いた実験装置の概略を Fig 3 に示す。 試料気体 (アルゴン) は可変リークバルブを通して気化し たヨウ素とミキシングチャンバーで混合する。またそのと き、この試料気体は室温に保たれており、その温度におけ るョウ素の室温蒸気压は26.5Pa(0.02torr) である。ミキシ ングチャンバー内で混合された気体はオリフィスを通り、 テストチャンバー内に噴出される。本実験では厚さ $0.1 \mathrm{~mm}$ のゲージ鋼板にドリルで内径 $0.3 \mathrm{~mm}$ の穴を 2 つ開ける平 行 2 軸噴流と 3 つ開ける平行 3 軸噴流（Fig2）で実験を行 った。またオリフィス間距離は $3 \mathrm{~mm}$ と $5 \mathrm{~mm}$ の二種類で行 った。チャンバー内の圧力を測定するのに高圧室側（ミキシ ングチャンバー) にCCM-1000(0.1 1.0 $1.010^{3}$ torr で可変、低 圧空側（テストチャンバー）に $\mathrm{CCMH}-1000(1.0 \times$ $10^{-3} \sim 1.0$ torr で可変のディジタル式王力変換器（キャパシタンスナ ノメーター、日本真空) を用いた。たチャンバー内の圧力は高王 室（ミキシングチャンバー）は圧力調整ポンプ（HITACHI GVD-135）を用い低圧室側（テストチャンバー）にはロー タリーポンプ (日本真空、 D-950DK) とメカニカルブースター ポンプ（日本真空、PMB-006C) を直列につなげて空気を排気 させた後、試料気体を流した。

レーザー光源としてはアルゴンイオンレーザー(プネウム:532-100MA、 レーザー径 $0.61 \mathrm{~mm}$ 、波長 $514.5 \mathrm{~mm}$ の緑色光）を用いたるの光を全反 射ミラー(シグマ光機) で反射させ、インテリジェントドライバー、コン トローラー PC-5K(シグマ光機)で反射ミラーを自動制御させた。

よう素の発する蛍光はたいんん微弱であるので、超音速自由噴流の像 を撮影するために、実験は暗公内で行い、暗視カメラのナイトヴュア (浜 松ホトニクス：C2100）を用い、営光以外の光を遮断するのにシャープ カットフィルター(SO56)をナイトヴュアに取り付けた。噴流の映像はフ イルム(ASA400) を用いナイトヴュアの上に取り付けたカメラ(Nikon F3）て露光させて映像を得た。インテリジェントコントローラーで露光 速度 $\mathrm{S} 2(0.1 \mathrm{~cm} / \mathrm{s})$ で光をスキャンニイングした。

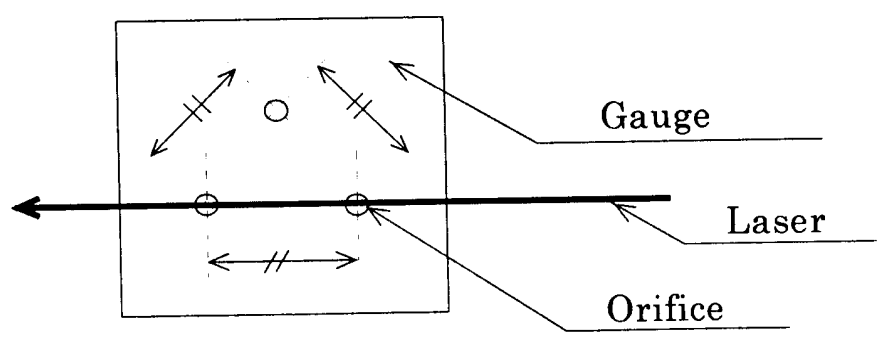

Fig. 2 Placement of triple Orifices

日本機械学会東海支部第52期総会講演会講演論文集

('03. 3. 14-15) No.033-1 


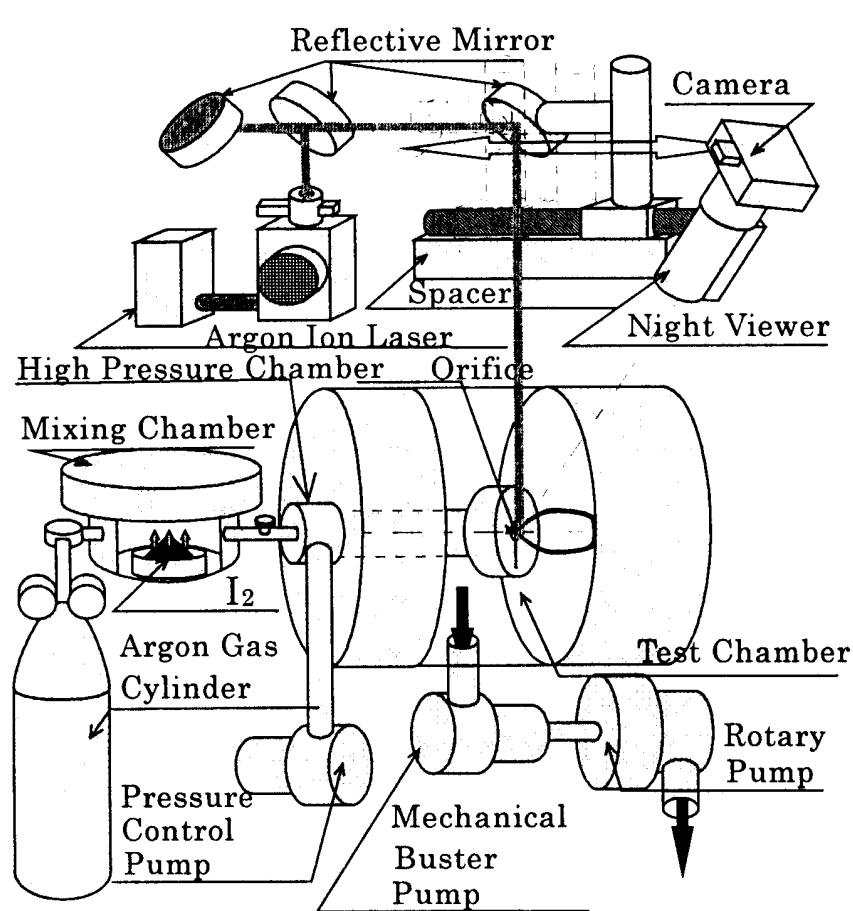

Fig.3 Experimental apparatus

\section{4. 実験結果および考察}

レーザー誘起蛍光法によって可視化されたオリフィス間距離 3 $\mathrm{mm} 、 の$ 平行 2 軸噴流、3 軸噴流の写真と平行 3 軸噴流の構造図 を Fig.4、Fig.5、同様に $5 \mathrm{~mm}$ の場合を Fig.6、Fig. 7 に示した。 明るくなっているところがヨウ素分子の多い所、つまり圧力が 高い所である。

Fig.4、5 のオリフィス間距離 $3 \mathrm{~mm}$ の平行 2 軸、3 軸噴流で は、膨張圧力と平衡した噴流境界の内にオリフィス 出口端から発生した“たる形衝撃波”(Barrel Shock) を有する構造となっている。また、両者とも噴流中 心軸間距離を 2 等分する軸Xに関して対称な構造と なり、その中心軸上で強く干渉している“斜め衝撃 波”(Oblique Shock)を有する。その干涉領域は“た る形衝撃波”が中心軸上で反射し形成した領域であ るため、平行 3 軸噴流の “斜め衝撃波” が三次元方向に大き くなり菱形のように膨らんだように見えたと考えられる (Fig.4 の Triple Jets）。また、その後流では“たる型衝撃波”がマッ 八反射をおこして“反射衝撃波”(Reflective Shock)、垂直衝撃 波（Normal Shock）を形成し、亜音速流になる。

Fig.6、7では、Fig.4、5 と比べて平行 2 軸噴流と 3 軸噴流の 両者とも“たる型衝撃波”が若干膨らんでいることが分かる。 これはオリフィス間距離が広くなったことで、“たる型衝撃波” の干涉が弱められたためだと思われる。また、3 軸噴流の “斜 め衝撃波”も同様に干渉が弱まったため、菱形を形成しなくな り、圧力も弱くなったと考えられる。

5. 結論

(1)オリフィスを通して高圧の気体を低圧領域に噴 射させた平行 2 軸噴流、3 軸噴流は、たる型衝撃波、

斜め衝撃波、垂直衝撃波、反射衝撃波で囲まれた干 涉領域を形成する。

(2)たる型衝撃波、斜め衝撃波、反射衝撃波はオリフィス間距 離が広くなると干渉によってその形状を変え、たる型衝撃波、

斜め衝撃波はY軸方向に膨らむ。

参考文献

藤本、他 2 名、日本機械学会論文集、

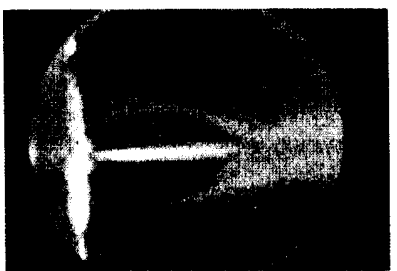

Double jets

$\mathrm{P}_{\mathrm{H}}=1000$ torr

$\mathrm{P}_{\mathrm{L}}=0.22$ torr

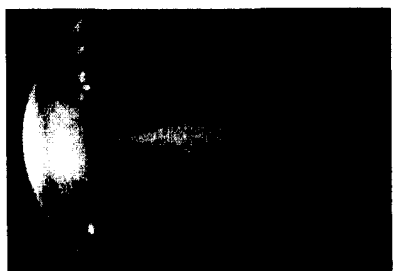

Triple

$\mathrm{P}_{\mathrm{H}}=1000$ torr

$P_{L}=0.22$ torr

Fig.4 Photograph of the jets $(3 \mathrm{~mm})$

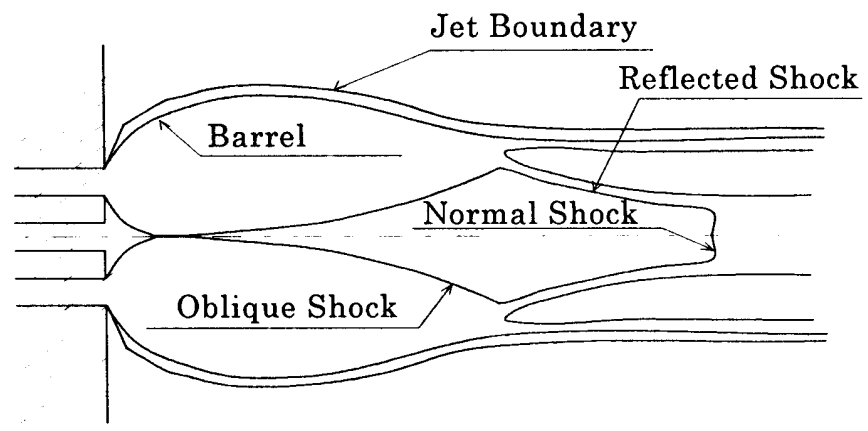

Fig. 5 Structure of the triple jets $(3 \mathrm{~mm})$

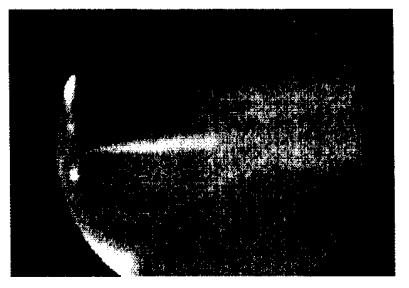

Double jets

$\mathrm{P}_{\mathrm{H}}=1000$ torr

$\mathrm{P}_{\mathrm{L}}=0.22$ torr

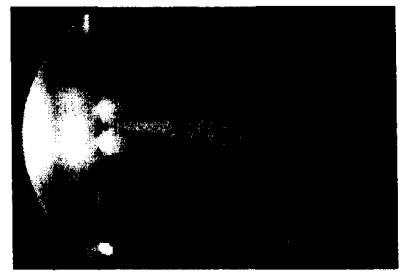

Triple jets

$\mathrm{P}_{\mathrm{H}}=1000$ torr

$\mathrm{P}_{\mathrm{L}}=0.22 \mathrm{torr}$

Fig.6 Photograph of the jets

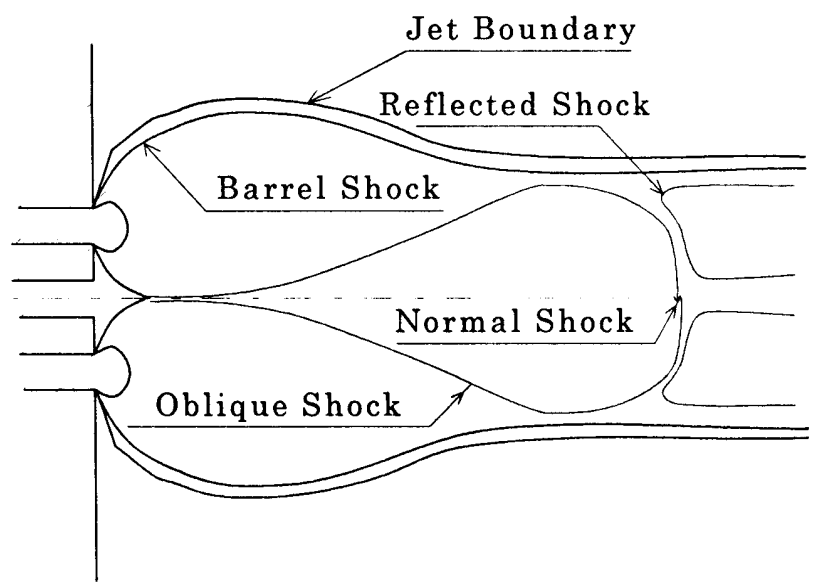

Fig. 7 Structure of the triple jets $(5 \mathrm{~mm})$ 